\title{
Association between low C-peptide and low lumbar bone mineral density in postmenopausal women without diabetes
}

\author{
T. Montalcini • P. Gallotti • A. Coppola • V. Zambianchi • \\ M. Fodaro • E. Galliera • M. G. Marazzi • S. Romeo • \\ S. Giannini • M. M. Corsi Romanelli • A. Pujia • \\ C. Gazzaruso
}

Received: 13 October 2014 / Accepted: 12 January 2015 /Published online: 24 January 2015

(C) The Author(s) 2015. This article is published with open access at Springerlink.com

\begin{abstract}
Summary In this population-based, cross-sectional study in Italian postmenopausal females not affected by diabetes, we showed a link between serum C-peptide and lumbar bone mineral density, suggesting that C-peptide exerts an insulin-independent effect on bone mass.
\end{abstract}

T. Montalcini $(\bowtie) \cdot S$. Romeo $\cdot$ A. Pujia

Clinical Nutrition Unit, Care Center in Menopause, Department of

Medical and Surgical Science, University Magna Grecia of

Catanzaro, Campus Universitario Germaneto, Viale S. Venuta,

88100 Catanzaro, Italy

e-mail: tmontalcini@unicz.it

P. Gallotti $\cdot$ A. Coppola $\cdot$ V. Zambianchi $\cdot$ M. Fodaro $\cdot$ C. Gazzaruso Internal Medicine, Diabetes, Vascular and Endocrine-Metabolic Diseases Unit and the Centre for Applied Clinical Research (Ce.R.C.A.) Clinical Institute "Beato Matteo", Vigevano, Italy

E. Galliera

Department of Biomedical, Surgical and Dental Science, University of Milan and Orthopaedic Institute IRCCS Galeazzi, Milan, Italy

M. G. Marazzi • M. M. Corsi Romanelli

Department of Health Biomedical Science, University of Milan and Unit of SMEL-1 Clinical Pathology Unit, San Donato Hospital IRCCS, San Donato Milanese, Milan, Italy

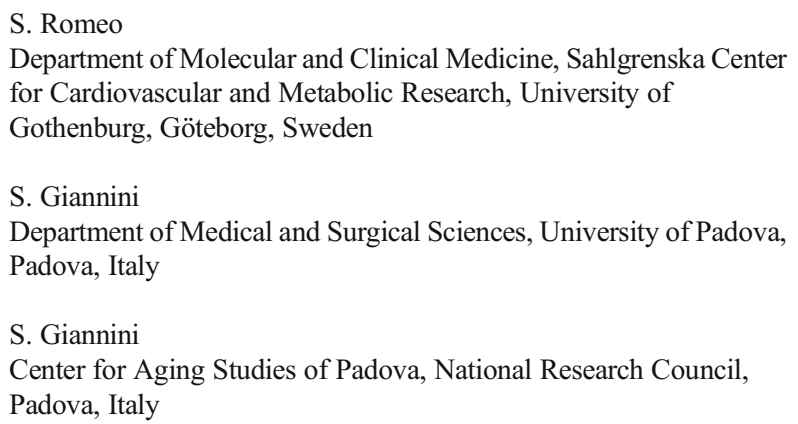

Introduction It is well known that type 1 (T1) diabetes, characterized by insulin and C-peptide deficiency, is associated with a low lumbar bone mineral density and an increased risk for fracture. While a role for insulin in the pathogenesis of osteoporosis has been demonstrated, the association between $\mathrm{C}$-peptide and the bone mineral density has not been investigated. We conducted a study in a cohort of 84 postmenopausal women without diabetes to clarify the association between serum C-peptide and the lumbar bone mineral density.

Methods Participants underwent a bone mineral density evaluation by DXA and biochemical analysis including the Cpeptide assay.

Results rteen percent of the population had osteoporosis and $38 \%$ had osteopenia. With ANOVA test, we showed that women with the lowest C-peptide concentration had lower lumbar mineral density in comparison to those in all other C-peptide concentration group ( $p=0.02$ among groups after adjustment). The univariate and multivariate analysis showed that C-peptide was positively associated with both lumbar T-score and Z-score besides other well-known factors like age (with T-score $p<0.001$; beta $=-0.38$ ) and BMI (with T-score $p=0.009$; be$\mathrm{ta}=0.34$ ), while insulin was not correlated with the lumbar bone mineral density. The area under the receiver operating characteristic (ROC) curve for C-peptide to predict the absence of lumbar osteoporosis was $0.74(\mathrm{SE}=0.073 ; p=0.013)$.

Conclusions These results suggest that C-peptide may exert an insulin- and BMI-independent effect on lumbar bone mineral density and that further large-scale studies are needed in order to clarify its role in bone mineralization especially in subjects without diabetes.

Keyword C-peptide $\cdot$ Lumbar bone mineral density · Menopause $\cdot$ Survey 


\section{Introduction}

Several studies have shown opposite results for type 1 (T1D) and type 2 diabetes (T2D) concerning the appearance of osteoporosis. In fact, it has been shown that a declined bone mineral density (BMD) associated with an increase in fracture risk in T1D [1-3] while an unpredictable BMD change and a variable fracture risk have been reported in T2D [2, 4].

In particular, it has been shown that the lumbar bone mineral density (LBMD) is lower in adolescents and adults with T1D compared to control population [5-7].

Insulin is crucial in osteoblast differentiation from marrow stromal cells [8]; thus, its role in the pathogenesis of osteoporosis in diabetes has been proposed [9]. However, insulin and C-peptide are secreted in equimolar concentrations from the pancreas. Since C-peptide has irrelevant extraction by the liver, constant peripheral clearance and its half-life is longer than insulin [10-12], it is commonly used in preference to insulin assessment. In addition, C-peptide has a central function in the synthesis and correct folding of insulin; therefore, a role also for C-peptide may be hypothesized in osteoporosis. Recent studies have demonstrated specific binding of C-peptide to cell surfaces(to pancreatic islets and red blood cells of rat and to cultured human renal tubular cells, fibroblasts, and endothelial cells) with the subsequent stimulation of specific intracellular processes involving $\mathrm{Na}^{+}-\mathrm{K}^{+}$-ATPase activity, a key mechanism for bone mineralization $[13,14]$. This finding may explain the positive correlation between both LBMD and femoral bone mineral density (FBMD) with C-peptide in patients with T1D [15]. However, a recent investigation has shown that serum C-peptide was negatively associated with BMD in individuals without diabetes and that this association was independent of the serum insulin levels and dependent of age [16]. Thus, at this moment, the definitive link between Cpeptide and BMD is not yet clarified and needs to be investigated. Consequently, we conducted a study in a cohort of postmenopausal women without diabetes to clarify the eventual association between serum C-peptide and both LBMD and FBMD. Furthermore, we examined whether other factors such parathyroid hormone (PTH), 25-OH vitamin D (the most important regulators of calcium homeostasis), and the fibroblast growth factor 23 (FGF-23) (the main phosphateregulating hormone) [17] were affecting this association.

\section{Methods}

This survey is in progress since 2011 in the regions of Lombardia and Calabria, Italy, and involves white postmenopausal female volunteers aged more than 45 years, invited by newspapers ads to participate in the study and consecutively enrolled. The subjects of this investigation consisted of the first
84 postmenopausal women without diabetes, who completed all the examinations at May 2014.

All participants underwent a brief interview to provide information about familiarity for osteoporosis, current physical exercise activity as the usual daily time spent outside walking (more than $30 \mathrm{~min}$ ) [18], smoke habits, medications use, and history of fractures. Pathological or high-energy fractures and fractures in sites not commonly associated with osteoporosis were not considered in the statistical analysis. Postmenopausal status was defined as the presence of a serum folliclestimulating hormone (FSH) level of over $40 \mathrm{IU} / 1$ (if available) or no natural menses for at least 1 year.

Subjects were excluded if they had self-report diagnosis of T1D or T2D and/or they were taking antidiabetic medication and/or insulin or they had fasting plasma glucose concentration equal or more than $126 \mathrm{mg} / \mathrm{dl}$, or any clinical condition that affects bone metabolism, such as diseases of the kidney, liver, thyroid, or parathyroids, rheumatic diseases, malabsorption syndromes, malignant tumors, and hematological diseases. None were taking drugs or hormones that influence bone metabolism, such as glucocorticoids, estrogens, thyroid hormone, fluoride, bisphosphonate, calcitonin, thiazide diuretics, barbiturates, vitamin $\mathrm{D}$, or calcium-containing drugs. All participants underwent both the LBMD and FBMD assessment, and a blood sample was collected for the biochemical analysis. We obtained their informed consent to participate in the study. The study was approved by both the Ethic Committee ASL Milan 2 and the University Hospital Mater Domini, Catanzaro. The investigation conforms to the principles outlined in the Declaration of Helsinki.

\section{DXA assessment}

Postmenopausal women underwent a BMD evaluation of the lumbar spine and left femur by DXA (Hologic QDR Inc., MA, USA, 17). BMD was expressed as the amount of mineral (g) divided by the area scanned $\left(\mathrm{cm}^{2}\right)$. Bone density was then expressed as the T-score, calculated on the basis of the normal reference values. The T-score is defined as the number of standard deviations from the healthy young adult mean (normal, $>-1$; osteopenia, -1 to -2.49 ; osteoporosis, $\leq-2.5$ ) while the Z-score was the number of standard deviations in comparison to healthy women of the same age $[19,20]$. The instrument was calibrated every day in accordance with the manufacturer's recommendations. The in vivo precision was established on the basis of repeated measurements in 30 women and was $<1 \%$.

\section{Nutritional calcium intake and anthropometric measurements}

The participant's nutritional calcium intake was calculated using the nutritional software MetaDieta 3.0.1 (MeTeDa srl, S. Benedetto del Tronto, Italy) [21] and categorized into two 
groups (normal intake-low intake). Body weight was measured before breakfast with the subjects lightly dressed, subtracting the weight of clothes. Body weight was measured with a calibrated scale and height measured with a wallmounted stadiometer. BMI was calculated with the following equation: weight $(\mathrm{kg}) /(\text { height }(\mathrm{m}))^{2}$

\section{Biochemical evaluation}

Venous blood was collected after fasting overnight into Vacutainer tubes (Becton \& Dickinson) and centrifuged within $2 \mathrm{~h}$. Serum glucose, phosphate, and hemoglobin A1c (HbAlc) were measured by standard laboratory techniques (enzymatic colorimetric test) [22]. Serum calcium (reference values (r.v.) $8.9-10.1 \mathrm{mg} / \mathrm{dL}$ ) was evaluated with a colorimetric assay according to Schwarzenbach, using $o$-cresolphthaleincomplexone [23]. Serum insulin was assessed with cheminumilescent microparticle immunoassay (CMIA) (ARCH ITECT insulin assay Abbott Laboratories, assay precision of $\leq 7 \%$ total coefficient variation (CV)). Standard C-peptide assay was performed with CMIA (ARCHITECT C-peptide assay Abbott, Germany; assay precision of $\leq 10 \%$ total CV). Concentrations of soluble FGF-23 (r.v. $10-50 \mathrm{pg} / \mathrm{ml}$ ) and N-terminal telopeptide (NTx) (r.v. 19-63 nM BCE/nM creatinine) in serum were determined by commercial ELISA assay (Human FGF-23 (C-term) ELISA Kit, San Clemente, CA, USA; Osteomark NTx serum ELISA, Wampole Laboratories, Princeton, NJ, USA). The intact PTH (r.v. $15-65 \mathrm{pg} / \mathrm{mL}$ ) and 25-hydroxyvitamin $\mathrm{D}$ [(25OH)D] (r.v. $30.0-100.0 \mathrm{ng} / \mathrm{mL}$ ) were measured by radioimmunoassay [24]. Internal quality control (IQC) was performed every day for all determination.

\section{Statistical analysis}

Data are reported as mean \pm standard deviation (SD). Eightyfive subjects are required to detect a correlation between Cpeptide and LBMD and FBMD equal to 0.30 , considered to be clinically meaningful, with $80 \%$ power on a two-sided level of significance of 0.05 .

A chi-square test was performed to analyze the difference of the prevalence between groups. The ANOVA was used to compare the means between groups (on the basis of C-peptide concentration tertiles) with Sheffe's post hoc test. Pearson correlation was used to identify the variables correlated to both the LBMD and FBMD expressed as T-score and Zscore (the number of SDs) given that the continuous variables were normally distributed. Non-normally distributed data were $\log$ transformed. The multivariate linear stepwise regression analysis was used to test the association between $\mathrm{C}$ peptide and BMD adjusting for confounding variables selected from univariate analysis having a $p<0.1$ (in model I), considering LBMD and FBMD (as T-score or Z-score) as dependent variables, in the separate analysis. In model II, in the multivariate linear stepwise regression analysis, we included also the log-transformed insulin. In model III, in the multivariate linear stepwise regression analysis we included, among confounding variables, also smoking, physical exercise, and familiarity for osteoporosis. The general linear model (GLM) was used to adjust LBMD (T-score value) for BMI and glucose. Furthermore, the area under the receiver operating characteristic (ROC) curve was used to analyze the capacity of C-peptide to predict the absence of osteoporosis at lumbar spine. Significant differences were assumed to be present at $p<0.05$ (two-tailed). All comparisons were performed using SPSS 20.0 for Windows (S. Wacker Drive, Chicago, IL 60606, USA).

\section{Results}

The mean age of the population was $56 \pm 6$ years. A total of 12 subjects $(14 \%)$ had osteoporosis, 32 (38\%) had osteopenia, and 40 (48 \%) had a normal BMD. Hypovitaminosis D was present in 18,40 , and $42 \%$ and familiarity for osteoporosis in 7,13 , and $50 \%$ of normal, osteopenic, and osteoporotic subjects, respectively. Only one subject did not complete all the examinations. Table 1 shows the characteristics of the study population. At univariate (Table 2, showing only factors significantly correlated to BMD) and multivariate

Table 1 Characteristics of whole non-diabetic population $(N=84)$

\begin{tabular}{lll}
\hline Variables & Mean & SD \\
\hline Age (years) & 53 & 6 \\
Weight $(\mathrm{Kg})$ & 66.0 & 14 \\
Height $(\mathrm{cm})$ & 161 & 7 \\
BMI $\left(\mathrm{kg} / \mathrm{m}^{2}\right)$ & 25 & 5 \\
Lumbar T-score & -0.94 & 1 \\
Lumbar Z-score & 0.03 & 1 \\
Femur Neck T-score & -1.13 & 1 \\
Femur neck Z-score & -0.25 & 1 \\
Phosphorus (mg/dL) & 3.6 & 0.4 \\
Calcium $(\mathrm{mg} / \mathrm{dL})$ & 9.4 & 0,4 \\
Glucose $(\mathrm{mg} / \mathrm{dL})$ & 91.2 & 9 \\
Insulin $(\mu \mathrm{d} / \mathrm{mL})$ & 8.4 & 4 \\
C-peptide $(\mathrm{ng} / \mathrm{mL})$ & 1.82 & 0.7 \\
HbA1c $(\%)$ & 5.6 & 0.2 \\
PTH (pg/mL) & 45.27 & 19 \\
Vitamin D $(\mathrm{ng} / \mathrm{mL})$ & 26.4 & 10 \\
NTx $(\mathrm{nM} \mathrm{BCE} / \mathrm{nM}$ creatinine) & 27.6 & 7 \\
FGF-23 (pg/mL) & 9.2 & 6 \\
\hline
\end{tabular}


Table 2 Univariate analysisPearson correlation

\begin{tabular}{lllcccccc}
\hline Variables & & Age & BMI & Insulin & C-peptide & Calcium & Vitamin D & Glucose \\
\hline LBMD & $r$ & - & 0.53 & 0.50 & 0.51 & - & - & 0.25 \\
(Z-score) & $p$ & - & $<0.001$ & $<0.001$ & $<0.001$ & - & - & 0.01 \\
LBMD & $r$ & -0.3 & 0.48 & 0.47 & 0.48 & -0.19 & - & 0.20 \\
(T-score) & $p$ & 0.001 & $<0-001$ & $<0.001$ & $<0.001$ & 0.07 & - & 0.05 \\
FBMD & $r$ & -0.37 & 0.47 & 0.38 & 0.34 & -0.19 & -0.23 & - \\
(T-score) & $p$ & $<0.001$ & $<0.001$ & 0.001 & 0.001 & 0.07 & 0.03 & - \\
\hline
\end{tabular}

(Table 3) analysis, after adjusting for confounding factors, there was no association between C-peptide and FBMD (both T-score, see Table 3, and Z-score, not showed), while C-peptide was associated with LBMD (with both T-score and Z-score, see Table 3) as well as age and BMI (with T-score: C-peptide $p=0.01$, beta $=0.33$; age $p<0.001$, beta $=-0.38$; BMI $p=0.009$, be$\mathrm{ta}=0.34$; variance inflation factor- $\mathrm{VIF}=1.91,1.00,1.92$ for C-peptide, age, and BMI, respectively; tolerance= $0.52,0.99,0.52$ for C-peptide, age, and BMI, respectively. Model I, Table 3). Interestingly, log-transformed insulin was not correlated with LBMD (with T-score: $p=0.66$; beta $0.072 ; t=0.43$, ,model II). In the multivariate analysis, the correlation between LBMD (measured by T-score) and glucose disappeared (models I, II, and III of Table 3, see legend). In addition, PTH, FGF-23, and $25-\mathrm{OH}$ vitamin $\mathrm{D}$ were not correlated (Table 2). Since BMI result correlated to C-peptide $(r=0.63$, $p<0.001)$, we performed a multivariate analysis with C-peptide corrected for BMI and the correlation did

Table 3 Multivariate linear regression analysis - factors correlated to both LBMD and FBMD

\begin{tabular}{|c|c|c|c|c|c|}
\hline $\begin{array}{l}\text { Dependent } \\
\text { variables }\end{array}$ & $\begin{array}{l}\text { Independent } \\
\text { variables }\end{array}$ & $\begin{array}{l}B \\
\text { value }\end{array}$ & $\begin{array}{l}\beta \\
\text { value }\end{array}$ & $\begin{array}{l}t \\
\text { value }\end{array}$ & $p$ value \\
\hline \multirow{3}{*}{$\begin{array}{l}\text { LBMD } \\
\text { T-score }^{\mathrm{a}}\end{array}$} & Age & -0.08 & -0.38 & -4.2 & $<0.001$ \\
\hline & BMI & 0.08 & 0.34 & 2.6 & 0.009 \\
\hline & C-peptide & 0.60 & 0.33 & 2.5 & 0.01 \\
\hline \multirow{2}{*}{$\begin{array}{l}\text { LBMD } \\
\text { Z-score }^{\text {b }}\end{array}$} & BMI & 0.08 & 0.34 & 2.8 & 0.005 \\
\hline & C-peptide & 0.50 & 0.29 & 2.4 & 0.01 \\
\hline \multirow{2}{*}{$\begin{array}{l}\text { FBMD } \\
\text { T-score }\end{array}$} & Age & -0.06 & -0.39 & -4.5 & $<0.001$ \\
\hline & BMI & 0.10 & 0.48 & 5.5 & $<0.001$ \\
\hline
\end{tabular}

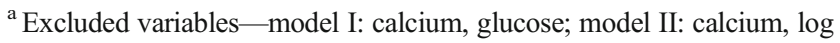
insulin, glucose; model III: calcium, log insulin, glucose, smoke, physical exercise, familiarity

${ }^{\mathrm{b}}$ Excluded variables - model I: log insulin, glucose; model II: log insulin, glucose, smoke, physical exercise, familiarity

${ }^{\mathrm{c}}$ Excluded variables-model I: calcium, $\log$ insulin, vitamin D, C-peptide; model II: calcium, log insulin, vitamin D, C-peptide, smoke, physical exercise, familiarity not change. To confirm all these associations, we categorized the population according to C-peptide tertiles. In Table 4, the prevalence of the risk factors for osteoporosis according to C-peptide tertiles is showed. Consequently, in the multivariate analysis, we further adjusted the data for smoke, physical exercise, and familiarity (Table 4) but these factors did not affect the associations (model III in Table 3, see legend, data not showed).

Table 5 shows the characteristic of the population according to C-peptide concentration tertiles. Analysis by ANOVA revealed that women with the lowest $\mathrm{C}$ peptide concentration (tertile I) had lower average LBMD (both $\mathrm{T}$-score and $\mathrm{Z}$-score) in comparison to those in all other tertiles $(p=0.03$ among tertiles; tertile I vs tertile III $p<0.001$; tertile II vs tertile III $p=0.019$, respectively; Table 5 and Fig. 1). Because of the significant difference in the BMI and glucose among Cpeptide tertiles (Table 5), a GLM was performed to adjust LBMD (T-score value) for these factors, confirming the lower LBMD in those with the lowest C-peptide ( $p=0.02$ after adjustment, Table 5). The area under the ROC curve for C-peptide to predict the absence of lumbar osteoporosis was $0.74(\mathrm{SE}=0.073 ; p=$ $0.013)$. The C-peptide equal to 1.31 achieved satisfactory sensitivity $(75 \%)$ and specificity $(60 \%)$ (Fig. 2$)$.

Table 4 Risk factor prevalence according to C-peptide tertiles

\begin{tabular}{lclll}
\hline Risk factors & I & II & III & $p$ value \\
& tertile & tertile & tertile \\
$N=28$ & $N=28$ & $N=28$ & \\
\hline $\begin{array}{l}\text { Current smokers (\%) } \\
\text { Normal calcium intake (\%) }\end{array}$ & 67 & 21 & 7 & 0.03 vs no smokers \\
Exercise habitually(\%) & 53 & 46 & 28 & $\begin{array}{c}0.33 \text { vs low } \\
\text { calcium intake }\end{array}$ \\
$\begin{array}{l}\text { Fractures (\%) } \\
\text { Familiar history for }\end{array}$ & 0 & 3 & 0 & $\begin{array}{c}0.33 \text { vs no } \\
\text { fractures }\end{array}$ \\
osteoporosis (\%) & 17 & 10 & 0 & $\begin{array}{c}0.05 \text { vs no familiar } \\
\text { history }\end{array}$ \\
\hline
\end{tabular}


Table 5 Characteristics of the whole population according to C-peptide concentration tertiles-ANOVA

\begin{tabular}{lllll}
\hline Variables & I tertile & II tertile & III tertile & $p$ value \\
\hline C-peptide range (ng/ml) & $0.80-1.36$ & $1.40-2.02$ & $2.03-3.80$ & \\
Age (years) & $54 \pm 7$ & $53 \pm 5$ & $52 \pm 5$ & 0.69 \\
BMI (kg/m $\left.{ }^{2}\right)$ & $25.7 \pm 5$ & $22.9 \pm 3$ & $26.4 \pm 5$ & 0.02 \\
LBMD T-score & $-1.28 \pm 1$ & $-1.10 \pm 1$ & $-0.43 \pm 1$ & 0.03 \\
& & & & $0.02^{\mathrm{a}}$ \\
LBMD Z-score & $-0.25 \pm 1$ & $-0.14 \pm 1$ & $0.51 \pm 1$ & 0.04 \\
FBMD T-score & $-1.15 \pm 1$ & $-1.30 \pm 1$ & $-0.95 \pm 1$ & 0.50 \\
FBMD Z-score & $-0.27 \pm 0.9$ & $-0.42 \pm 1$ & $-0.06 \pm 1$ & 0.43 \\
Calcium (mg/dL) & $9.4 \pm 0.3$ & $9.4 \pm 0.4$ & $9.3 \pm 0.4$ & 0.78 \\
Phosphorus (mg/dL) & $3.6 \pm 0.4$ & $3.5 \pm 0.5$ & $3.7 \pm 0.3$ & 0.35 \\
Glucose (mg/dL) & $88.2 \pm 8$ & $89.1 \pm 9$ & $96.3 \pm 9$ & 0.003 \\
Insulin ( $\mu \mathrm{U} / \mathrm{mL})$ & $6.5 \pm 3$ & $7.1 \pm 2$ & $11.9 \pm 4$ & $<0.001$ \\
C-peptide (ng/mL) & $1.3 \pm 0.4$ & $1.6 \pm 0.3$ & $2.5 \pm 0.5$ & $<0.001$ \\
HbA1c (\%) & $5.6 \pm 0.2$ & $5.6 \pm 0.3$ & $5.7 \pm 0.3$ & 0.69 \\
PTH (pg/mL) & $47.6 \pm 18$ & $45.8 \pm 21$ & $42.1 \pm 18$ & 0.54 \\
25OH vit D (ng/mL) & $25.1 \pm 11$ & $25.9 \pm 9$ & $27.9 \pm 11$ & 0.59 \\
NTx (nM BCE/nM & $25.8 \pm 8$ & $27.5 \pm 6$ & $28.9 \pm 7$ & 0.37 \\
$\quad$ creatinine) & & & & \\
FGF-23 (pg/mL) & $10.6 \pm 8$ & $8.1 \pm 4$ & $9.3 \pm 5$ & 0.35 \\
\hline
\end{tabular}

${ }^{\text {a }}$ LBMD: T-score, glucose, and BMI adjusted in the GLM

\section{Discussion}

The results of this population-based, cross-sectional study in Italian postmenopausal females not affected by diabetes showed that serum C-peptide was strongly associated with LBMD (with both T-score and Z-score value) (Table 2) also after adjustment for several factors (Table 3). In addition, the main calcium-phosphate regulating hormones (PTH, 25-OH vitamin $\mathrm{D}$, and the FGF-23) did not affect this association that was also independent of the serum insulin. We also found that postmenopausal women in the lowest serum C-peptide concentration tertile had the lower LBMD in comparison to those in the highest C-peptide tertiles (Table 5). With these results, we infer that a low C-peptide concentration could be a novel osteopenic marker in postmenopausal women not affected by diabetes, if confirmed.

It is well known that T1D, that is characterized by an insulin and C-peptide deficiency, is associated with a low LBMD and an increased risk for fracture [1, 2, 5-7]. A role for insulin in osteoblastogenesis has been proposed [25]. Furthermore, recent investigations have suggested that C-peptide is not biologically inert but that it is a separate entity with different characteristics from those of insulin [13]. It has been shown that $\mathrm{C}$-peptide involves the activation of $\mathrm{Ca} 2+$-dependent signaling pathways with consequent stimulation of $\mathrm{Na}+-\mathrm{K}+-$ ATPase [13] via specific binding as a ligand to its receptor.
The transfer of inorganic phosphate into osteoblastic cells, important in bone formation, is related to the transmembrane electrochemical gradient of sodium maintained by $\mathrm{Na}, \mathrm{K}$ ATPase [14]. In addition, bone mineralization critically depends upon optimal calcium homeostasis in osteoblasts. To establish optimal intracellular $\left[\mathrm{Ca}^{2+}\right]$, osteoblasts need CaATPase and $\mathrm{Na} / \mathrm{Ca}$ exchange systems whose activities depend on the activity of Na,K-ATPase [26]. Thus, C-peptide may be not only a marker but it may also have an active role in the development of osteoporosis. However, whether C-peptide acts also in concert with insulin remains to be elucidated. In this contest, it is important reflect also on the role of the islet amyloid pancreatic polypeptide (IAPP, amylin) that is a hormone co-secreted with both insulin and C-peptide from beta cells. Patients with T1D are also deficient in IAPP. Amylin has been implicated in bone physiology. In fact, genetic ablation of amylin leads to bone loss in mice [27] and treatment with amylin can in part reverse bone loss in ovariectomized rats [28]. Analysis of amylin gene supports an evolutionary relationship to calcitonin [29]. In addition, a positive association between amylin levels and BMD in women with anorexia nervosa has been reported [30]. Thus, a number of investigations suggest a role for the pancreatic hormones on bone metabolism.

A potential explanation of link between C-peptide and LBMD may be the role of BMI conditioning the association. In fact, hyperinsulinemia and insulin resistance are highly correlated with BMI [31] and, in turn, they affect the bone. As expected, in our investigation, we found a strong correlation between BMI and C-peptide. To exclude any interference, we corrected C-peptide for BMI but the results did not change. Therefore, although BMI may be a confounding factor, there is sufficient evidence to suggest that $\mathrm{C}$-peptide may exert a BMI-independent effect on bone mass, providing a further link between nutrient intake and bone turnover. In this regard, it has been showed that C-peptide predicted visceral fat accumulation in both short-term and long-term follow-up [32]; thus, the hormonal changes may precede and predict the BMI increase as suggested from other studies showing that the secretion of bone-active hormones from the pancreas may explain part of the relationship between fat mass and bone mass [31]. However, further large-scale studies need to be performed in order to clarify the role of the hormones secreted by beta cells on bone metabolism especially in subjects not affect by diabetes.

Of course, the link between C-peptide and BMD is still neglected and needs to be studied in deep in experimental study. In a recent investigation, using data from the NHAN ES [16], a negative association between serum C-peptide and BMD (expressed in $\mathrm{g} / \mathrm{cm}^{2}$ ) was found independent of the serum insulin levels. However, in the 40-59 years age group, the group similar to our population, the authors showed that, after additional data adjustment, the serum C-peptide levels 
Fig. 1 Scatter plot with the individual data of the correlation between LBMD and C-peptide

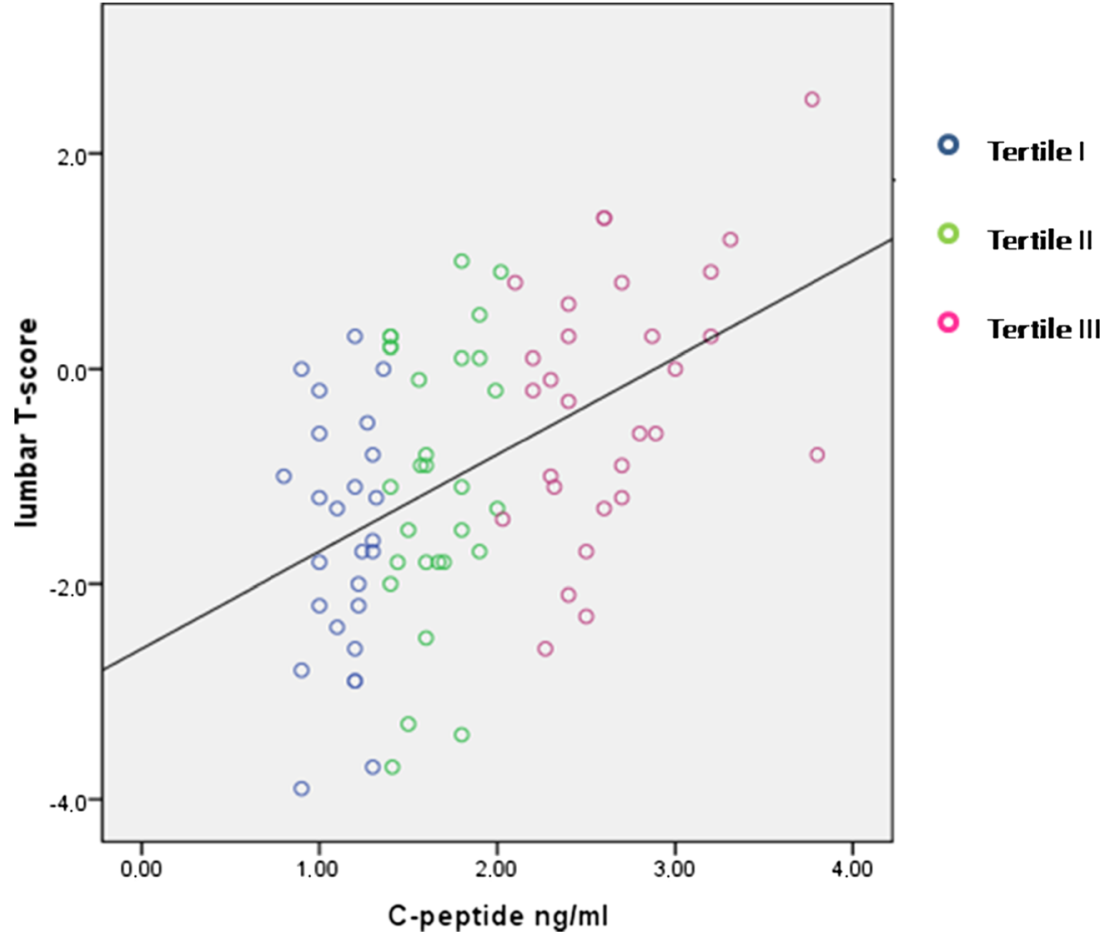

were not associated with the spinal BMD [16]. In that study, there was a lack of information about the measurement of serum C-peptide [16]. Our study differs from that investigation in several points: We studied specifically postmenopausal women without diabetes and in a definite age range; we reported plasma glucose concentration of the whole population (that was in normal range); we defined low BMD according to the T-score and Z-score; whole-body DXA scan was not performed in our study; we assessed C-peptide with a definite methods. Finally, we investigated the effects of the interaction with other factors on BMD like PTH, 25-OHvitamin D, and FGF-23. Our findings are in agreement with a previous investigation [15] showing a positive correlation between both LBMD and FBMD and C-peptide levels in patients with
Fig. 2 The area under the ROC curve for C-peptide to predict the lumbar osteoporosis

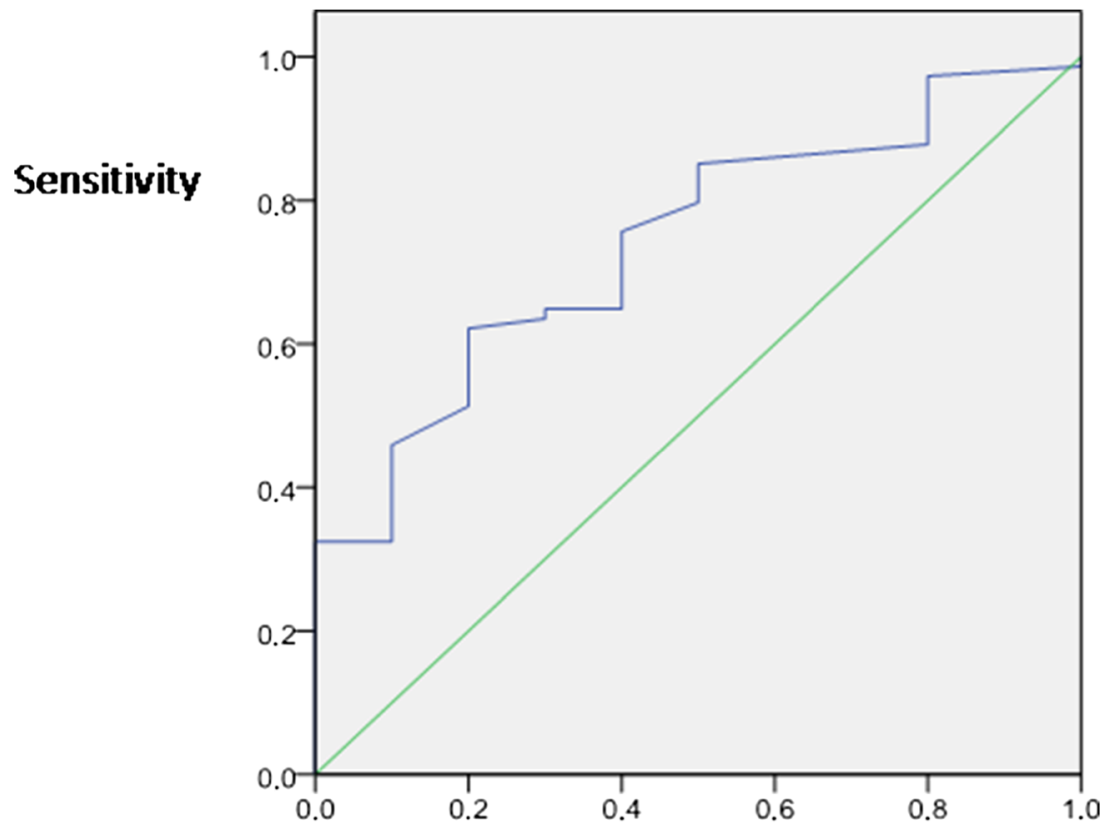

Specificity 
T1D. C-peptide, insulin, and amylin seem to be associated with $\mathrm{BMD}$ in the same manner. C-peptide is commonly used in clinical practice in preference to insulin assessment [10-12]. Thus, in the future, C-peptide may be also measured to predict lumbar osteoporosis, if its role will be confirmed. In our population, we found a positive correlation between C-peptide and NTx $(r=0.22$ and $p=0.05$, data not showed) while a negative correlation was expected. However, this finding is plausible since we showed that postmenopausal women of the I tertile (those with the lower C-peptide concentration and in which a greater NTx was expected) exercise habitually more than those of all other groups (Table 3). In this regard, several studies reported that both the walking exercise and a high-impact exercise training decreased NTx levels in postmenopausal osteopenic women [33, 34]. Physical exercise appears to suppress bone turnover; thus, it is plausible that in our investigation, women in the I tertile had also lower NTx concentration (Table 2; I vs III tertile, $p=0.009$, in the post hoc analysis), affecting the correlation between $\mathrm{C}$ peptide and NTx.

This study has several limitations that must be addressed. The study could not determine causality. Furthermore, our study was limited by its small size and cross-sectional design. However, the statistical analysis is robust and adequate. The clinical significance of the low C-peptide in osteoporosis could be well deduced from the present results. The investigation was done on representative samples of the Italian population; in fact, the study was conducted across two institutions, potentially increasing the generalizability of our findings from a geographical perspective. Our results were not purely random as established by previous investigations [13, 26 ] and further confirmed by multiple analyses (as showed by the statistical power and by the absence of collinearity and interaction between variables, see the "Results" section). Of course, this study may serve to generate hypotheses and documenting this observation in "in vitro" research in the future may be of great interest.

Unfortunately, we did not assess any marker of bone formation but one of resorption alone as NTx. However, this is in line with other investigations $[35,36]$.

Further studies are warranted to investigate the potential relationship between C-peptide and bone loss in other population and to confirm that C-peptide could become a helpful clinical tool in the assessment of osteoporosis.

Acknowledgments The authors thank the Vigevano and Piacenza Foundation for its support.

\section{Conflicts of interest None.}

Open Access This article is distributed under the terms of the Creative Commons Attribution Noncommercial License which permits any noncommercial use, distribution, and reproduction in any medium, provided the original author(s) and the source are credited.

\section{References}

1. Tuominen JT, Impivaara O, Puukka P, Rönnemaa T (1999) Bone mineral density in patients with type 1 and type 2 diabetes. Diabetes Care 22:1196-1200

2. Forsén L, Meyer HE, Midthjell K, Edna TH (1999) Diabetes mellitus and the incidence of hip fracture: results from the Nord-Trondelag Health Survey. Diabetologia 42:920-925

3. Vestergaard P (2007) Discrepancies in bone mineral density and fracture risk in patients with type 1 and type 2 diabetes: a meta-analysis. Osteoporos Int 18:427-444

4. van Daele PL, Stolk RP, Burger H, Algra D, Grobbee DE, Hofman A, Birkenhäger JC, Pols HA (1995) Bone density in non-insulindependent diabetes mellitus. The Rotterdam Study. Ann Intern Med 122:409-414

5. Ponder SW, McCormick DP, Fawcett HD, Tran AD, Ogelsby GW, Brouhard BH, Travis LB (1992) Bone mineral density of the lumbar vertebrae in children and adolescents with insulin-dependent diabetes mellitus. J Pediatr 120:541-545

6. Gunczler P, Lanes R, Paz-Martinez V, Martins R, Esaa S, Colmenares V, Weisinger JR (1998) Decreased lumbar spine bone mass and low bone turnover in children and adolescents with insulin dependent diabetes mellitus followed longitudinally. J Pediatr Endocrinol Metab 11:413-419

7. Valerio G, del Puente A, Esposito-del Puente A, Buono P, Mozzillo E, Franzese A (2002) The lumbar bone mineral density is affected by long-term poor metabolic control in adolescents with type 1 diabetes mellitus. Horm Res 58:266-272

8. Avnet S, Perut F, Salerno M, Sciacca L, Baldini N (2012) Insulin receptor isoforms are differently expressed during human osteoblastogenesis. Differentiation 83:242-248

9. Barrett-Connor E, Kritz-Silverstein D (1996) Does hyperinsulinemia preserve bone? Diabetes Care 9:1388-1392

10. Jones AG, Hattersley AT (2013) The clinical utility of C-peptide measurement in the care of patients with diabetes. Diabet Med 30: 803-817

11. Polonsky KS, Licinio-Paixao J, Given BD, Pugh W, Rue P, Galloway J, Karrison T, Frank B (1986) Use of biosynthetic human C-peptide in the measurement of insulin secretion rates in normal volunteers and type I diabetic patients. J Clin Invest 77:98-105

12. Licinio-Paixao J, Polonsky KS, Given BD, Pugh W, Ostrega D, Frank BF, Rubenstein AH (1986) Ingestion of a mixed meal does not affect the metabolic clearance rate of biosynthetic human C-peptide. J Clin Endocrinol Metab 63:401-403

13. Wahren J, Ekberg K, Johansson J, Henriksson M, Pramanik A, Johansson BL, Rigler R, Jörnvall H (2000) Role of Cpeptide in human physiology. Am J Physiol Endocrinol Metab 278:759-768

14. Caverzasio J, Selz T, Bonjour JP (1988) Characteristics of phosphate transport into osteoblast-like cells. Calcif Tissue Int 43:83-87

15. López-Ibarra PJ, Pastor MM, Escobar-Jiménez F, Pardo MD, González AG, Luna JD, Requena ME, Diosdado MA (2001) Bone mineral density at time of clinical diagnosis of adult-onset type 1 diabetes mellitus. Endocr Pract 7:346-351

16. Li Y, Liu H, Sato Y (2013) The association between the serum Cpeptide level and bone mineral density. PLoS One 8:e83107. doi:10. 1371/journal.pone.0083107

17. Jüppner H, Wolf M, Salusky IB (2010) FGF-23: More than a regulator of renal phosphate handling? J Bone Miner Res 25:2091-2097. doi:10.1002/jbmr.170

18. Adami S, Giannini S, Giorgino R et al (2003) The effect of age, and lifestyle factors on calcaneal quantitative ultrasound: the ESOPO study. Osteoporos Int 14:198-207 
19. Glynn NW, Meilahn EN, Charron M, Anderson SJ, Kuller LH, Cauley JA (1995) Determinants of bone mineral density in older men. J Bone Miner Res 10:1769-1777

20. Report of a WHO Study Group (1994) World Health Organization: assessment of fracture risk and its application to screening for postmenopausal osteoporosis. World Health Organ Tech Rep Ser 843:1129

21. Montalcini T, Lamprinoudi T, Morrone A, Mazza E, Gazzaruso C, Romeo S, Pujia A (2014) Nutrients utilization in obese individuals with and without hypertriglyceridemia. Nutrients 6:790-708. doi:10. 3390/nu6020790

22. Mazziotti G, Gola M, Bianchi A, Porcelli T, Giampietro A, Cimino V, Doga M, Gazzaruso C, De Marinis L, Giustina A (2011) Influence of diabetes mellitus on vertebral fractures in men with acromegaly. Endocrine 40:102-108

23. Montalcini T, Terracciano R, Romeo S, Foti D, Gulletta E, Costanzo FS, Pujia A (2012) Postmenopausal women with carotid atherosclerosis: potential role of the serum calcium levels. Nutr Metab Cardiovasc Dis 23:1141-1146. doi:10.1016/j.numecd.2012.12.004

24. Foti D, Greco M, Cantiello F, Damiano R, Gulletta E, Pujia A, Montalcini T (2014) Hypovitaminosis D and low urinary tract symptoms in a female population. Eur J Inflamm 12:365-372

25. Hofbauer LC, Brueck CC, Singh SK, Dobnig H (2007) Osteoporosis in patients with diabetes mellitus. J Bone Miner Res 22:1317-1328

26. Francis MJ, Lees RL, Trujillo E, Martín-Vasallo P, Heersche JN, Mobasheri A (2002) ATPase pumps in osteoclasts and osteoblasts. Int J Biochem Cell Biol 34:459-476

27. Dacquin R, Davey RA, Laplace C, Levasseur R, Morris HA, Goldring SR, Gebre-Medhin S, Galson DL, Zajac JD, Karsenty G (2004) Amylin inhibits bone resorption while the calcitonin receptor controls bone formation in vivo. J Cell Biol 164:509-514
28. Horcajada-Molteni MN, Davicco MJ, Lebecque P, Coxam V, Young AA, Barlet JP (2000) Amylin inhibits ovariectomy-induced bone loss in rats. J Endocrinol 165:663-668

29. Steiner DF, Ohagi S, Nagamatsu S, Bell GI, Nishi M (1991) Is islet amyloid polypeptide a significant factor in pathogenesis or pathophysiology of diabetes? Diabetes 40:305-309

30. Wojcik MH, Meenaghan E, Lawson EA, Misra M, Klibanski A, Miller KK (2010) Reduced amylin levels are associated with low bone mineral density in women with anorexia nervosa. Bone 46: 796-80

31. Zhao LJ, Jiang H, Papasian CJ, Maulik D, Drees B, Hamilton J, Deng HW (2008) Correlation of obesity and osteoporosis: effect of fat mass on the determination of osteoporosis. Bone Miner Res 23:17-29

32. Tong J, Fujimoto WY, Kahn SE, Weigle DS, McNeely MJ, Leonetti DL, Shofer JB, Boyko EJ (2005) Insulin, C-peptide, and leptin concentrations predict increased visceral adiposity at 5- and 10-year follow-ups in nondiabetic Japanese Americans. Diabetes 54:985-990

33. Yamazaki S, Ichimura S, Iwamoto J, Takeda T, Toyama Y (2004) Effect of walking exercise on bone metabolism in postmenopausal women with osteopenia/osteoporosis. J Bone Miner Metab 22:500-550

34. Basat H, Esmaeilzadeh S, Eskiyurt N (2013) The effects of strengthening and high-impact exercises on bone metabolism and quality of life in postmenopausal women: a randomized controlled trial. J Back Musculoskelet Rehabil 26:427-435

35. Khalil N, Sutton-Tyrrell K, Strotmeyer ES, Greendale GA, Vuga M, Selzer F, Crandall CJ, Cauley JA (2011) Menopausal bone changes and incident fractures in diabetic women: a cohort study. Osteoporos Int 22:1367-1376

36. Bollen AM, Kiyak HA, Eyre DR (1997) Longitudinal evaluation of a bone resorption marker in elderly subjects. Osteoporos Int 7:544-549 